\title{
BIOLOGICAL EFFICIENCY OF LIPIDS IN RAINBOWN TROUT FLESH DEPENDING ON PROTEIN LEVELS IN FEEDS
}

V. M. KONDRATIUK, PhD in Agricultural sciences, Associate Professor, https://orcid.org/0000-0002-4246-2639

E-mail: vadkondratyk@ukr.net

\author{
A. O. IVANIUTA, PhD in Technical Sciences, Assistant, \\ https://orcid.org/0000-0002-1770-5774, \\ E-mail: ivanyta07@gmail.com
}

National University of Life and Environmental Sciences of Ukraine https://doi.org/10.31548/dopovidi2021.02.009

Abstract. The article considers the effect of using complete feeds with different protein levels on the biological efficiency of rainbow trout flesh lipids. The purpose of the experiment was to determine the effect of different levels of commercial rainbow trout's protein nutrition on the fatty acid composition of flesh lipids and their biological effectiveness. For this purpose, five experimental groups were formed by the method of analogues. The experiment lasted 210 days and was divided into two periods: equalization (10 days) and basic (200 days). During the equalization period, the experimental fish consumed feed of the control group. In the main period, the level of protein in experimental feeds for different experimental groups of trout ranged from 44 to $52 \%$ per $1 \mathrm{~kg}$.

Rainbow trouts were fed 4-6 times a day during the experimental period, at regular intervals during the day. The required amount of feed was calculated according to the indices of individual fish weight and ambient temperature at the time of feeding. Commercial second-summer trouts were reared in ponds with an area of $100 \mathrm{~m}^{2}$ at the fish-holding density of 50 specimens $/ \mathrm{m}^{2}$ and the water level of $1 \mathrm{~m}$. The total number of trout in the experimental studies was 25 thousand specimens.

It has been established that the consumption of compound feed with different levels of crude protein by second-year rainbow trout significantly affects the changes in the fatty acid composition of theirflesh. As a result of the study it was found that the dominant fatty acids are oleic (C18: 1) - 14.44-18.92\% and palmitoleic (C16: 1) - 5.19-11.09\%. The increase in the level of crude protein in the feed of commercial rainbow trout to 52 $\%$ contributed to an increase in the content of saturated fatty acids in flesh by $7.9 \%$ compared to the control. It has also been found that the use of compound feeds with a high level of protein nutrition lead to a decrease in the content of stearic acid in flesh. The results of experimental studies showed that among the polyunsaturated fatty acids in the lipids of rainbow trout's flesh, the highest content beloned to linoleic fatty acid (C18: 2) - 1.76-2.2\%.

Key words: rainbow trout, fish feeding, compound feeds, protein, flesh, lipids, fatty acid composition

Background. Fat content is one of the main indices by which one can characterize the value of a particular species of fish. The content of many fatty 
Кондратюк В. М., Іванюта А. О.

acids in fish lipids varies considerably, which, according to researchers, depends on the species of fish, food composition and temperature for their their existence.

Rainbow trout flesh contains 5 to $23.5 \%$ of fat. An important feature is that the lipids of rainbow trout contain a great content of highly unsaturated fatty acids (linoleic, eicosapentaenoic and docosahexaenoic), which is due to the peculiarities of their nutrition. Eicosapentaenoic acid and $\omega-3$ unsaturated fatty acids formed by it are first synthesized by algae and then moved down the food chain into fish flesh. This, in turn, permits rainbow trout flesh to be characterized as a dietary food. Accordingly, an important factor that purposefully affects the biological efficiency of lipids in rainbow trout flesh is the completeness of protein nutrition.

In the research works of Faritov T.A., Egorov B.V., Figurskaya L.V., Sherman I.M., Khan K., Shcherbin M.A.and others, the issue of biological value of lipids of rainbow trout flesh depending on various factors is considered [1-5]. However, there are no studies on the fatty acid composition of rainbow trout flesh lipids and their biological efficiency depending on protein levels in feeds.

Thus, the study of different commercial rainbow trout's protein nutrition impact on the biological efficiency of its flesh in modern industrial conditions of cold-water fish farms of
Ukraine is necessary and possesses great economic importance.

Materials and methods. Experimental studies on two-year-old rainbow trout Oncorhynchus mykiss (Walbaum, 1792) were performed in the "Shipot" farm, Perechyn district of the Transcarpathian region.

The purpose of the scientific and economic experiment was to establish the effect of different levels of commercial rainbow trout's protein nutrition on the biological efficiency of flesh lipids and their fatty acid composition.

For this purpose, five experimental groups were formed by the method of analogues (table 1). During the equalization period of the experiment, which lasted 10 days, the experimental fish consumed the feed of the control group. In the main period of the experiment (200 days) the level of protein in the feed of the experimental groups trout was regulated by changing the individual components of the feed (using combined mathematical methods to optimize the calculation using the Agro Soft Win Opti software).

The nutritional value of experimental production feeds is shown in table 2.

Rainbow trout were fed 4-6 times a day during the experimental period, at regular intervals during the day. The required amount of feed was calculated according to the indices of individual fish weight and ambient temperature at the time of feeding. 
Кондратюк В. М., Іванюта А. О.

1. Design of scientific and economic experiment

\begin{tabular}{|c|c|c|c|c|}
\hline \multirow{3}{*}{ Group of fish } & \multirow{3}{*}{$\begin{array}{l}\text { Fish-holding density } \\
\text { at the beginning of the } \\
\text { experiment,specim. } / \mathrm{m}^{2}\end{array}$} & \multirow{3}{*}{$\begin{array}{l}\text { Mean weight } \\
\text { at the } \\
\text { beginning of } \\
\text { the } \\
\text { experiment, } g\end{array}$} & \multicolumn{2}{|c|}{ Experimental periods } \\
\hline & & & $\begin{array}{c}\text { equalization (10 } \\
\text { days) }\end{array}$ & $\begin{array}{c}\text { main }(200 \\
\text { days })\end{array}$ \\
\hline & & & \multicolumn{2}{|c|}{ protein content in $1 \mathrm{~kg}$ of feed, $\%$} \\
\hline 1- control & 50 & $55.3 \pm 2.48$ & \multirow{5}{*}{48} & 48 \\
\hline 2- experimental & 50 & $56.1 \pm 2.13$ & & 44 \\
\hline 3- experimental & 50 & $54.8 \pm 2.37$ & & 46 \\
\hline 4- experimental & 50 & $55.1 \pm 3.13$ & & 50 \\
\hline 5- experimental & 50 & $54.5 \pm 2.99$ & & 52 \\
\hline
\end{tabular}

Weighing of experimental trout was performed once every 10 days by means of electronic scales in a calibrated container with water, with an accuracy up to $0.1 \mathrm{~g}$. The total number of trout in the experimental studies was 25 thousand specimens. Conditions for keeping experimental fish met the regulatory requirements in salmon farming [6-7].

2. Content in $1 \mathrm{~kg}$ of compound feed, $\%$

\begin{tabular}{|l|c|c|c|c|c|}
\hline \multirow{2}{*}{\multicolumn{1}{|c|}{ Index }} & \multicolumn{5}{c|}{ Groups } \\
\cline { 2 - 6 } & 1-st & 2-nd & 3-rd & 4-th & 5 -th \\
\hline Metabolizable energy, MJ & 17,00 & 17,00 & 17,00 & 17,00 & 17,00 \\
\hline Crude protein & 48,00 & 44,00 & 46,00 & 50,00 & 52,00 \\
\hline Crude fat & 18,00 & 18,00 & 18,00 & 18,00 & 18,00 \\
\hline Crude fiber & 2,40 & 2,45 & 2,71 & 2,91 & 2,77 \\
\hline Calcium & 1,80 & 1,80 & 1,80 & 1,80 & 1,80 \\
\hline Total phosphorus & 1,20 & 1,20 & 1,20 & 1,20 & 1,20 \\
\hline Lysin & 2,70 & 2,70 & 2,70 & 2,70 & 2,70 \\
\hline Methionine & 0,90 & 0,90 & 0,90 & 0,90 & 0,90 \\
\hline Vitamin A, thousand IU & 10 & 10 & 10 & 10 & 10 \\
\hline Vitamin D3, thousand IU & 3 & 3 & 3 & 3 & 3 \\
\hline Vitamin E, mg & 200 & 200 & 200 & 200 & 200 \\
\hline
\end{tabular}

The mass fraction of lipids was determined by the Soxhlet method according to DSTU 8717: 2017, that says the fat is weighed after its extraction with a solvent from a dry sample in the Soxhlet extraction apparatus, based on determining the change in sample weight after solvent extraction of fat [8].

The content of fatty acids was determined by chromatographic method on the "Kupol 55" chromatograph. Identification of peaks in the chromatogram was performed by the method of of "carbon numbers" calculation, as well as by using chemically pure, standard solutions, methyl esters of fatty acids. The individual fatty acids content calculation based on the results of gas chromatographic analysis chromatograms - was performed according to a formula that included correction factors for each of them. The correction factors were found as the ratio 
Кондратюк В. М., Іванюта А. О.

of the peak areas (including peak heights) of heptadecanoic (internal standard) and test acid at a concentration of $1: 1$ and the isothermal mode of operation of the gasliquid chromatograph.

Mass fraction of polyunsaturated fatty acids (PUFA) - By chromatographic method with the HRGC 5300 chromatograph [9]; lipid extraction - by the methods of Folch and Blay-Dyer [10]; lipid efficiency coefficient - by the calculation method [11]; the lipids biological value factor (BVF) was calculated as the ratio of the sum of PUFA eicosapentaenoic and docosahexaenoic acids to the mass fraction of fat in the product [12]. The study results were processed by the method of variation statistics using the STATISTICA 7.0. software and MS Excel using built-in statistical functions [13].

\section{Results of the study and their} discussion. The nutritional value of lipids is determined by the presence of lipid nature substances, such as phospholipids, fat-soluble vitamins, sterols and fatty acid composition of lipids. The fatty acid composition of rainbow trout is characterized by a relatively large amount of monounsaturated fatty acids. Dominant fatty acids are oleic (C18: 1) 14.44-18.92\% and palmitoleic (C16: 1) - 5.19-11.09\% (table 3).

3. Fatty acid lipid composition of rainbow trout flesh, $n=5, M \pm m$

\begin{tabular}{|c|c|c|c|c|c|c|}
\hline \multirow[t]{2}{*}{ Fatty acids } & \multirow{3}{*}{$\begin{array}{c}\text { FA } \\
\text { Code }\end{array}$} & \multicolumn{5}{|c|}{ Groups } \\
\hline & & $1-\mathrm{st}$ & 2-nd & 3-rd & 4-th & 5-th \\
\hline Saturated (SFA) & & 45.85 & 43.14 & 42.35 & 45.03 & 45.71 \\
\hline myristic acid & $14: 0$ & $2.69 \pm 0.09$ & $2.12 \pm 0.04^{* * *}$ & $2.19 \pm 0.06^{* *}$ & $2.98 \pm 0.10$ & $3.02 \pm 0.12$ \\
\hline palmitic acid & $16: 0$ & $21.05 \pm 1.46$ & $18.14 \pm 1.28$ & $18.08 \pm 1.22$ & $21.48 \pm 1.72$ & $21.54 \pm 1.69$ \\
\hline stearic acid & 18:0 & $3.19 \pm 0.16$ & $3.21 \pm 0.17$ & $3.03 \pm 0.12$ & $3.44 \pm 0.22$ & $3.11 \pm 0.11$ \\
\hline arachic acid & $20: 0$ & $0.82 \pm 0.02$ & $0.63 \pm 0.01^{\text {**** }}$ & $0.74 \pm 0.01^{* *}$ & $1.03 \pm 0.03^{* * * *}$ & $1.12 \pm 0.03^{* * *}$ \\
\hline neodecanoic acid & 19:0 & $18.10 \pm 1.98$ & $19.04 \pm 1.79$ & $18.31 \pm 1.69$ & $16.13 \pm 1.14$ & $16.92 \pm 1.14$ \\
\hline $\begin{array}{l}\text { Monounsaturated } \\
\text { (MUFA) }\end{array}$ & & 45.36 & 40.99 & 34.81 & 46.63 & 47.69 \\
\hline palmitoleic acid & $16: 1$ & $10.15 \pm 0.52$ & $9.44 \pm 0.36$ & $5.19 \pm 0.21^{* * *}$ & $10.62 \pm 0.44$ & $11.09 \pm 0.36$ \\
\hline$\omega_{9}$ oleic acid & $18: 1$ & $18.31 \pm 1.79$ & $16.31 \pm 1.32$ & $14.44 \pm 1.16$ & $18.62 \pm 1.62$ & $18.92 \pm 1.71$ \\
\hline$\omega_{9}$ elaidic acid & $18: 1$ & $1.78 \pm 0.05$ & $1.49 \pm 0.07^{* *}$ & $1.14 \pm 0.06^{* * *}$ & $2.05 \pm 0.10^{*}$ & $2.44 \pm 0.14^{* *}$ \\
\hline gadoleic acid & $20: 1$ & $15.12 \pm 1.94$ & $13.75 \pm 2.01$ & $14.04 \pm 1.69$ & $15.34 \pm 1.21$ & $15.24 \pm 1.14$ \\
\hline $\begin{array}{l}\text { Polyunsaturated } \\
\text { (PUFA) }\end{array}$ & & 3.6 & 3.35 & 3.15 & 3.73 & 4.18 \\
\hline$\omega_{3}$ linoleic acid & $18: 2$ & $1.92 \pm 0.09$ & $1.88 \pm 0.05$ & $1.76 \pm 0.06$ & $2.00 \pm 0.08$ & $2.20 \pm 0.07^{*}$ \\
\hline$\omega_{6}$ linolenoic acid & $18: 3$ & $0.83 \pm 0.02$ & $0.81 \pm 0.02$ & $0.75 \pm 0.02^{*}$ & $0.82 \pm 0.03$ & $0.94 \pm 0.04^{*}$ \\
\hline eicosadienoic acid & $20: 2$ & $0.85 \pm 0.02$ & $0.66 \pm 0.01^{* * *}$ & $0.64 \pm 0.01^{* * * *}$ & $0.91 \pm 0.01^{*}$ & $1.04 \pm 0.04^{* *}$ \\
\hline Unidentified & & 5.19 & 12.52 & 19.69 & 2.58 & 2.42 \\
\hline
\end{tabular}

Studies have shown that feeding second-summer rainbow trouts with compound feeds containing different levels of crude protein significantly affects the changes in the fatty acid composition of their flesh.

Thus, the increase in the level of crude protein in the feed of commercial 
Кондратюк В. М., Іванюта А. О.

rainbow trout in all experimental groups, compared to the control, contributed to a slight decrease in the content of saturated fatty acids in flesh. The established difference is statistically significant in the flesh of fish in experimental group 3 (p $<0.05)$.

Among saturated fatty acids, the total share of which in the flesh of secondsummer trout is $42.35-45.85 \%$, in the lipids of rainbow trout the highest content of palmitic acid was found (C16: 0$)-$ 18.08-21.54\%.

A similar pattern is established in the amount of such saturated fatty acids as palmitic. In particular, with an increase of protein content in the diets of rainbow trout by $4 \%$, their flesh contained by 44.6 $\%$ more palmitic acid than analogues in experimental group 3 ( $\mathrm{p}<0.01$ ) and by 2.3 $\%$ compared to the control.

It was also found that the use of compound feed with a high level of protein nutrition for feeding fish leads to a decrease in the content of stearic acid in flesh. Thus, its amount in the flesh of rainbow trout in group 5 was by 2.6-10.6 $\%$ less than in fish of other experimental groups.

It is characteristic that feeding young trout in experimental groups 3 and 4during all age periods of rearing complete feed with low protein levels, contributes to positive changes in the fatty acid composition of their flesh. Thus, in terms of the saturated fatty acids amount in flesh, fish of groups 3 and 4 outperformed the analogues of the control group by $8.3 \%$ and $6.3 \%$, respectively.
At the same time, an increase in the content of palmitic and neodecanoic acids compared to the control was detected.

The proportion of trout polyunsaturated fatty acids in trout flesh lipids is relatively high. Predominant are linoleic (C18: 2) - 1.76-2.2\% and linolenoic acids (C18: 3) - 0.75-0.94\% .

Thus, the studied fish raw material has a high content of essential fatty acids, which indicates its high value.

High molecular weight fatty acids that contain at least two double bonds (linoleic, linolenoic, arachic acids) cannot be synthesized in the human body and are therefore essential. The absence of these acids leads to a lack of vitamins in the body. Essential fatty acids help reduce blood cholesterol. Consumption of $30 \mathrm{~g}$ of fish oil reduces the amount of cholesterol contained in human blood by $7 \%$.

By fractions from the amount of fatty acids MUFA makes to 34.81$47.69 \%$, UFA - 42.35-45.71\%, PUFA $3.15-4.18 \%$. The lipids of secondsummer rainbow trout, regardless of the factor under study, are dominated by fatty acids with 16 and 18 carbon atoms. The highest content was observed for oleic, palmitic, palmitoleic and linoleic fatty acids. Fatty acids with 20-22 carbon atoms in the molecule and with 5-6 double bonds are the most active.

It was found that among PUFAs in the lipids of rainbow trout flesh the highest content belongs to linoleic fatty acid (C18: 2) - 1.76-2.2\%. Polyunsaturated fatty acids - linoleic, linolenic and arachic acid, are part of 
Кондратюк В. М., Іванюта А. О.

vitamin $\mathrm{F}$ and are vital, physiologically obligatory, essential fatty acids. These acids provide a number of extremely important functions of the animal body: normal growth, development and formation of skin cells, its nutrition, favorable course of pregnancy and lactation; normal cholesterol transfer (reduction of its level), normal pressure in the subcutaneous blood vessels, stability and normal vascular elasticity.

Indices of the biological efficiency of lipids in second-summer rainbow trout's flesh are shown in table 4.

Table 4

Indices of lipid biological efficiency in second-summer trout's flesh, $n=5$

\begin{tabular}{|c|c|c|c|c|}
\hline \multirow{2}{*}{ Group } & \multicolumn{4}{|c|}{ Ratio of FA types } \\
\cline { 2 - 5 } & UFA:MUFA:PUFA & PUFA:UFA & C18:2:C:18:1 & $\omega_{6}: \omega_{3}$ \\
\hline Ideal lipid & $1: 1: 1$ & $0.2: 0.4$ & $>0.25$ & $10: 1$ \\
\hline 1-st & $1: 0.99: 0.08$ & $0.08: 1$ & $1: 9.53$ & $1: 2.31$ \\
\hline 2-nd & $1: 0.95: 0.08$ & $0.08: 1$ & $1: 8.68$ & $1: 2.32$ \\
\hline 3-rd & $1: 0.82: 0.07$ & $0.07: 1$ & $1: 8.20$ & $1: 2.35$ \\
\hline 4-th & $1: 1.04: 0.08$ & $0.08: 1$ & $1: 9.31$ & $1: 2.44$ \\
\hline 5-th & $1: 1.04: 0.08$ & $0.08: 1$ & $1: 8.60$ & $1: 2.34$ \\
\hline
\end{tabular}

The ratio of individual lipid classes in the muscle tissue of rainbow trout meets the standards proposed by nutritionists, in particular the ratio of fatty acids $\omega 6: \omega 3$ in the experimental samples of rainbow trout is within the range of 1 : 2.31-1: 2.44 .

\section{Conclusions}

1. As a result of the studies performed the influence of different levels of protein nutrition fed to marketable rainbow trout on the fatty acid composition of flesh lipids and their biological efficiency was revealed.

2. It is established that feeding young trout in experimental groups 2 and 3 with complete feed with low protein levels, during all age periods of rearing, contributes to changes in the fatty acid composition of their flesh. Thus, fish of groups 2 and 3 outperformed the analogues of the control group in the amount of saturated fatty acids in flesh by $8.3 \%$ and $6.3 \%$, respectively.

3. Results of the study confirm the presence of a relatively large amount of monounsaturated fatty acids in the lipidcomposition of rainbow trout flesh: oleic (C18: 1) - 14.44-18.92 \%; palmitoleic (C16: 1) - 5.19-11.09\%. Among saturated fatty acids, palmitic acid (C16: 0$)-18.08-21.54 \%$ is dominant.

4. Analysis of the obtained results showed that the fractions from the amount of fatty acids MUFA makes to 34.81$47.69 \%$, UFA- $42.35-45.71 \%$, PUFA $3.15-4.18 \%$.

5. It has been clarified that fatty acids with 16 and 18 carbon atoms are predominant in the flesh lipids of rainbow trout, regardless of the studied factor. The content is dominated by oleic, palmitic, palmitoleic and linoleic fatty acids. 
Кондратюк В. М., Іванюта А. О.

\section{Список використаних джерел}

1. Фаритов Т. А. Кормление рыб / за ред. Данеленко В.Г. Учебное пособие. Лань. 2016. С. 352.

2. Сгоров Б. В., Фігурська Л. В. Порівняльний аналіз поживної цінності комбікормів для форелі. Зернові продукти і комбікорми. №3 (43). 2011. С. 38-43.

3. Шерман I. М., Гринжевський М. В., Желтов Ю. О. Наукове обгрунтування раціональної годівлі риб: учебное пособие. Вища освіта, 2002. С. 128.

4. Khan K., Rodrigues A., Cleber M. et al. Dietary protein quality and proper protein to energy ratios: a bioeconomic approach in aquaculture feeding practices. Latin American Journal of Aquatic Research. 2019. № 47(2). P. 232-239.

5. Щербина М. А., Гамыгин Е. А. Кормление рыб в пресноводной аквакультуре. М.: ВНИРО, 2006. 360 с.

6. Соврачев К. Ф. Основы биохимии и питания рыб. Москва : Легкая и пищевая промышленность, 1982. $247 \mathrm{c}$.

7. Канидьев А. Н. Инструкция по разведению радужной форели. Москва:ВНИИПРХ, 1985.59 с.

8. ДСТУ 8717:2017 Риба та рибні продукти. Методи визначення жиру.

9. Байдалинова Л. С., Кривич В. С., Бахолдина Л. П. Методические рекомендации и указания по газовой хроматографии жирных кислот. Калининград, 1977. 33 с.

10. Blight E. G. и Dyer W. J., A rapid method of total lipid extraction and purification. Can. J. Biochem. Physiol. 1959. 37, 911-917.

11. Рогов И. А., Антипова Л. В., Дунченко Н. И. Химия пищи. М. : КолосС, 2007. 853 с.

12. Байдалинова Л. С., Лысова А. С., Мезенова О. Я., Сергеева Н. Т. и др. Биотехнология морепродуктов. Учебник с грифом ФАР. М.: Мир, 2006. 560 с.

13. Плохинский Н.А. Руководство по биометрии для зоотехников. М.: Колос, 1969. 246 c.

\section{References}

1. Yehorov B. V., Fihurska L. V. (2011). Stan ta perspektyvy rozvytku forelivnytstva u rybovodnykh hospodarstvakh Ukrainy[Status and prospects of trout farming development in fish farms of Ukraine]. Zernovi produkty $\mathrm{i}$ kombikormy. 2; 37-39.

2. Faritov T.A. (2016.) Kormlenie ryb [Fish feeding]. Danelenko V.G., redaktor: Uchebnoe posobie . Lan'. 352 p.

3. Sherman I.M., Hrynzhevskyi M.V., Zheltov Yu.O. (2002). Naukove obhruntuvannia ratsionalnoi hodivli ryb: uchebnoe posobye.[ Scientific substantiation of rational feeding of fishes: the textbook. Manual] Vyshcha osvita. p. 128.

4. Khan K., A. Rodrigues, M. Cleber. (2019). Dietary protein quality and proper protein to energy ratios: a bioeconomic approach in aquaculture feeding practices. Latin American Journal of Aquatic Research. 47(2):232-239.

5. Shcherbyna M. A., Hamyhyn E. A. (2006.) Kormlenye ryb $\mathrm{v}$ presnovodnoi akvakulture. [Fish feeding in freshwater aquaculture] Moskva: VNIRO. 360 p.

6. Sovrachev K.F. (1982). Fundamentals of biochemistry and fish nutrition. Moscow: Light and food industry, $247 \mathrm{p}$.

7. Kanidyev A.N. Gamygin E.A. (1987). Progressivnye metody kormleniya raduzhnoj foreli [Advanced methods for feeding rainbow trout]. Tr. VNIRO, Sadkovoe vyrashchivanie foreli [Cage farming of trout], 1977; 76: 109116.

8. DSTU 8717:2017 Ryba ta rybni produkty. Metody vyznachennia zhyru. [Fish and fish products. Methods for determining fat] (2017).

9. Baidalynova L.S. Kryvych V.S., Bakholdyna L.P. (1977) Metodycheskye rekomendatsyy y ukazanyia po hazovoi khromatohrafyy zhyrnokh kyslot [Guidelines and instructions for gas chromatography of fatty acids]. Kaliningrad, $33 \mathrm{p}$.

10. Blight ЕG и Dyer WJ (1959).A rapid method of total lipid extraction and purification. Can. J. Biochem. Physiol. 37, 911-917.

11. Rogov, I.A., Antipova, N.I., Dunchenko, N.I. (2007). Khimia pishchi [Chemistry of food]. Moscow: Kolos C. 853 p.

12. Baidalynova L.S., Lysova A.S.,. Mezenova O.Ia, Serheeva N.T. i dr. (2006). Byotekhnolohyia moreproduktov. Uchebnyk s hryfom FAR [Seafood Biotechnology. Manual]. M.: Mir, 560 p. 
Кондратюк В. М., Іванюта А. О.

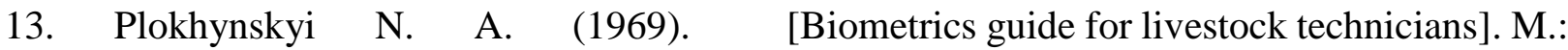
Rukovodstvo po byometryy dlia zootekhnykov Kolos. 246 p.

\section{БІОЛОГІЧНА ЕФЕКТИВНІСТЬ ЛІПІДІВ М'ЯСА РАЙДУЖНОЇ ФОРЕЛІ ЗАЛЕЖНО ВІД РІВНІВ ПРОТЕЇНУ У КОМБІКОРМАХ В. М. Кондратюк, А. О. Іванюта}

Анотація. Вміст жиру - один із основних показників, за яким можна характеризувати цінність того чи іншого виду риби. Вміст багатьох жирних кислот у ліпідах риб коливається в значних межах, щзо залежить, на думку науковців, від виду риб, складу їжі і температури, їхнього існування.

М'ясо райдужної форелі містить від 5 до 23,5 \% жиру. Важливою особливістю є те, щзо ліпіди райдужної форелі містять великий вміст високоненасичених жирних кислот (лінолевої, ейкозопентаєнової $i$ докозогексаєнової), щуо пояснюється особливостями їх жнилення. Ейкозопентаєнова кислота і створювані за ї̈ рахунок ненасичені жирні кислоти

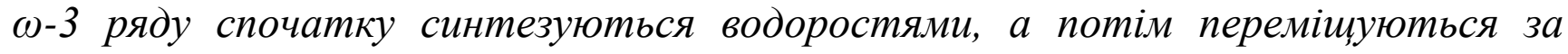
харчовим ланцюгом у м'ясо риб. Це, в свою чергу, дозволяє характеризувати м'ясо райдужної форелі як дієтичний продукт харчування. Відповідно, важливим чинником, щзо изілеспрямовано впливає на біологічну ефективність ліпідів м'яса райдужної форелі є повноцінність протеїнового живлення.

Експериментальні дослідження на дволітках райдужної форелі Oncorhynchus mykiss (Walbaum, 1792) проведені в умовах господарства «Шипот» Перечинського району Закарпатської області.

Метою науково-господарського досліду передбачалося встановити вплив різних рівнів протеїнового живлення товарної райдужної форелі на показники біологічної ефективності ліпідів м'яса та їх жсинокислотний склад.

Для цьього за методом аналогів було сформовано n'ять піддослідних груп У зрівняльний період досліду, який тривав 10 діб піддослідна риба споживала комбікорм контрольної групи. В основний період досліду (200 діб) рівень протеїну в комбікормах форелі дослідних груп регулювали за рахунок зміни окремих компонентів комбікормів (з використанням комбінованих математичних методів оптимізації розрахунку за допомогою програми Agro Soft Win Opti).

Годівлю райдужної форелі в період досліджень проводили 4-6 раз на добу, в денний час через рівні проміжки. Необхідну кількість корму розраховували відповідно до показників індивідуальної маси риб та температури середовища на момент годівлі.

Зважування піддослідної форелі проводили раз на 10 діб на електронних терезах у відтарованій ємкості з водою, з точністю до 0,1 г. Вирошування товарних дволітків проводили в ставах площуею $100 \mathrm{M}^{2}$ за щзільності посадки 50 екз./м², та рівня води в них 1 м. Загальна кількість особин форелі в експериментальних дослідженнях становила 25 тис. екз. Умови утримання піддослідних риб відповідали нормативним вимогам у лососівництві [6-7]. 


\section{Кондратюк В. М., Іванюта А. О.}

Результати досліджень опраџььовані методом варіаџійної статистики за допомогою програмного забезпечення STATISTICA 7.0. і MS Excel з використанням вбудованих статистичних функиій [13].

Харчова цінність ліпідів визначається наявністю речовин ліпідної природи, таких як фосфоліпіди, жиророзчинні вітаміни, стерини та жсирнкислотним складом ліпідів.

Жирнокислотний склад райдужної форелі характеризується відносно великою кількістю мононенасичених жирних кислот. Домінуючими жирними кислотами с олеїнова $\left(C_{18: 1}\right)-14,44-18,92 \%$ п пальмітоолеїнова $\left(C_{16: 1}\right)-5,19-11,09$ $\%$.

Проведеними дослідження виявлено, щзо під впливом споживання дволітками райдужної форелі комбікормів з різним рівнем сирого протеїну помітно впливає на зміни у жсирнокислотному складі їхнього м'яса.

Так, підвищення рівня сирого протеїну у комбікормах товарної райдужной форелі у всіх дослідних групах, порівняно з контролем, сприяло незначному знипженню вмісту у м'ясі суми насичених жсиних кислот.

Серед насичених жирних кислот, загальна частка яких у м'ясі дволітків складає 42,35-45,85\%, у ліпідах райдужної форелі виявлено найбільший вміст пальмітинової кислоти $\left(C_{16: 0}\right)-18,08-21,54 \%$.

Аналогічна закономірність виявлена $і$ за кількістю такої насиченої жирної кислоти, як пальмітинова. Зокрема, за підвищення вмісту протеїну в раціонах райдужної форелі на 4\%, у їхньому м'ясі містилося пальмітинової кислоти на 44,6 \% більще, ніж у аналогів 3- $і$ дослідної групи $(P<0,01)$ та 2,3\% порівняно 3 контролем.

Встановлено також, щз використання для годівлі риб 5-ї групи комбікормів з підвищеним рівнем протеїнового живлення призводить до зниження вмісту $у$ м'ясі стеаринової кислоти. Так, ї̈ кількість у м'ясі райдужної форелі 5-ї групи була на 2,6-10,6 \% меншою, порівняно з аналогічними показниками у риб дослідних гpyn.

Характерно, щуо згодовування молоді форелі 3-ї та 4-ї дослідних груп упродовж усіх вікових періодів вирощування повнораціонних комбікормів із зниженим рівнем протеїну, сприяє позитивним змінам жирнокислотного складу їхнього м'яса. Так, за кількістю насичених жирних кислот у м'ясі, риби 3-ї та 4-ї груп переважали аналогів контрольної групи відповідно на 8,3% та 6,3\%. Одночасно виявлено вірогідне зростання вмісту пальмітинової та нанодеканової кислот порівняно з контролем.

У ліпідах м'яса форелі відносно високою є частка поліненасичених жирних кислот. Переважаючими виступають лінолева $\left(C_{18: 2}\right)$ - 1,76-2,2 \% та ліноленова $\left(C_{18: 3}\right)-0,75-0,94 \%$.

Таким чином, досліджувана рибна сировина відрізняється високим вмістом есенцііальних жирних кислот, щуо свідчить про ї̈ високу циінність.

За фракціями від суми жирних кислот МНЖК належить 34,81-47,69\%, НЖК - 42,35-45,71\%, ПНЖК-3,15-4,18\%. В ліпідах м'яса дволітків райдужної форелі, незалежно від досліджуваного фактора, переважають жирні кислоти з 16 та 18 атомами вуглецью. Найбільший вміст відмічений для олеїнової, пальмітинової, 


\section{Кондратюк В. М., Іванюта А. О.}

пальмітоолеїнової та лінолевої жирних кислот. Жирні кислоти з 20-22 атомами вуглецую в молекулі та з 5-6 подвійними зв'язками є найбільш активними.

Виявлено, щуо серед ПНЖК у ліпідах м'яса райдужної форелі найбільший вміст належить лінолевій жирній кислоті $\left(C_{18: 2}\right)$ - 1,76-2,2\%. Поліненасичені жирні кислоти - лінолева, ліноленова і арахідонова, входять до складу вітаміну $F$ і відносяться до життєво важливих, фізіологічно необхідних, есенційних жирних кислот. Ці кислоти забезпечують ряд украй важливих функцій тваринного організму: нормальний ріст, розвиток і утворення клітин икіри, ї̈ живлення, сприятливе протікання вагітності $i$ лактації; нормальне перенесення холестерину (зниження його рівня), нормальний тиск в підикірних кровоносних судинах, стійкість і нормальну еластичність судин.

Співвідношення окремих класів ліпідів у м'язовій тканині райдужної форелі відповідає запропонованим фахівцями з нутрищіології нормам, зокрема співвідношення жирних кислот $\omega_{6}: \omega_{3}$ перебуває у піддослідних зразках райдужної форелі в межах 1:2,31-1:2,44.

Ключові слова: райдужна форель, годівля риби, комбікорми, білки, м'якоть, ліпіди, склад жирних кислот 